\section{PERLAKUAN TERHADAP TAWANAN PERANG MENURUT HUKUM HUMANITER INTERNASIONAL ${ }^{1}$ \\ Oleh: Senta Esterlita Ayomi ${ }^{2}$ \\ Natalia L. Lengkong ${ }^{3}$ \\ Stefan Obadja Voges ${ }^{4}$}

\begin{abstract}
ABSTRAK
Tujuan dilakukannya penelitian ini yaitu untuk
\end{abstract} mengetahui bagaimana menetapkan status tawanan perang dalam situasi konflik bersenjata dan bagaimana perlakuan terhadap tawanan perang Hukum Humaniter Internasional yang dengan metode penelitian hukum normatif disimpulkan: 1. Hukum Humaniter Internasional menentukan bahwa seseorang yang berstatus sebagai combatant (dalam hal ini lawful combatant) otomatis berhak diperlakukan sebagai tawanan perang (prisoner of war) apabila mereka tidak mampu lagi melanjutkan pertempuran dan tertangkap pihak lawan. Tetapi ada juga sekelompok penduduk sipil tertentu, walaupun mereka bukan kombatan, apabila jatuh ke tangan musuh berhak pula mendapatkan status prisoner of war sebagaimana yang diatur dalam Pasal 4A dan 4B Konvensi Jenewa III Tahun 1949. Ketentuan tentang siapa yang berhak mendapatkan status dan perlakuan sebagai tawanan perang (prisoner of war) telah disempurnakan dalam Protokol I Tahun 1977, diatur dalam pasal 43,44, 45. Kemudian dalam Konvensi Jenewa IV disebutkan pula bahwa status tawanan perang tidak termasuk para nonkombatan yang tidak bersenjata saat ditangkap pada masa perang, mereka itu dilindungi. 2. Tawanan perang itu harus diperlakukan dengan baik karena hak-hak mereka diatur didalam Konvensi Jenewa III Tahun 1949 yaitu hak mendapatkan perlakuan manusiawi, hak kehormatan martabat dan harga diri, hak perawatan medis, hak memperoleh perlakuan yang adil, hak melaksanakan ritual keagamaan, hak aktivitas mental dan fisik, hak mendapatkan kebutuhan primer seperti sandang, pangan dan papan dan hak berkomunikasi dengan dunia luar.

\footnotetext{
${ }^{1}$ Artikel Skripsi

2 Mahasiswa pada Fakultas Hukum Unsrat, NIM. 16071101056

${ }^{3}$ Fakultas Hukum Unsrat, Doktor IImu Hukum

${ }^{4}$ Fakultas Hukum Unsrat, Magister Ilmu Hukum
}

Kata kunci: tawanan perang; hukum humaniter;

\section{PENDAHULUAN}

\section{A. Latar Belakang}

Terdapat juga prinsip kemanusiaan sebagai salah satu prinsip dasar dalam Hukum Humaniter Internasional, dimaksudkan dalam memberikan bantuan tanpa diskriminasi kepada orang yang teruka di medan perang , berupaya dengan kapasitas internasional dan nasional untuk mengurangi penderitaan manusia dimanapun ditemukan prinsip ini. Selain itu, prinsip ini bermanfaat untuk meningkatkan saling pengertian, pesahabatan, kerjasama dan perdamaian yang bekelanjutan diantara semua rakyat sehingga tidak menciptakan diskriminasi karena kebangsaan, ras, kepercayaan agama, pendapat kelas atau politik. Sebagai prinsip dasar Hukum Humaniter Internasional, para pihak yang bersengketa diharuskan untuk memperhatikan perikemanusiaan, dimana mereka dilarang untuk menggunakan kekerasan yang dapat menimbulkan luka yang berlebihan atau penderitaan yang tidak perlu termasuk kepada tawanan perang. ${ }^{5}$

\section{B. Perumusan Masalah}

1. Bagaimana menetapkan status tawanan perang dalam situasi konflik bersenjata ?

2. Bagaimana perlakuan terhadap tawanan perang Hukum Humaniter Internasional?

\section{E. Metode Penelitian}

Penelitian ini merupakan penelitian jenis penelitian hukum normatif.

\section{PEMBAHASAN}

\section{A. Menetapkan Status Tawanan Perang Dalam Situasi Konflik Bersenjata}

Secara umum tawanan perang itu merupakan tentara yang ditangkap dalam masa perang, tetapi bukan hanya tentara saja yang ikut dalam berperang atau berkonflik terdapat anggota milisi dan korps sukarelawan lain, termasuk anggota gerakan perlawanan terorganisasi, yang menjadi bagian dari salah satu pihak yang berkonflik. Hukum Humaniter Internasional juga menentukan bahwa

\footnotetext{
5 DANIAL "Penghormatan prinsip-prinsip kemanusiaan terhadap tawanan perang dalam konflik bersenjata
} menurut onvensi Jenewa III Tahun 1949" Hm. 1. 
seseorang yang berstatus sebagai combatant (dalam hal ini lawful combatant) otomatis berhak diperlakukan sebagai prisoner of war apabila mereka tidak mampu lagi melanjutkan pertempuran dan tertangkap pihak lawan. Tetapi ada pula sekelompok penduduk sipil tertentu, walaupun mereka bukan kombatan, apabila jatuh ke tangan musuh berhak pula mendapatkan status prisoner of war sebagaiaman yang diatur dalam Pasal 4A Konvensi Jenewa III tahun $1949 .^{6}$ Pasal ini menyebutkan bahwa mereka yang berhak mendapatkan status sebagai tawanan perang (prisoner of war) adalah sebagai berikut: ${ }^{7}$

a. Para anggota angkatan perang dari pihak yang bersengketa, anggota-anggota milisi atau korps sukarela yang merupakan bagian dari angkatan perang itu.

b. Para anggota milisi lainnya, termasuk gerakan perlawanan yang diorganisasikan (organized resistance movement) yang tergolong pada satu pihak yang bersengketa dan beroperasi di dalam atau di luar wilayah mereka, sekalipun wilayah itu diduduki, dan memenuhi syarat-syarat sebagai berikut:

1. dipimpin oleh orang yang bertanggung jawab atas bawahannya;

2. menggunakan tanda pengenal tetap yang dapat dilihat dari jauh;

3. membawa senjata secara terbuka;

4. melakukan operasinya sesuai dengan hukum dan kebiasaan perang.

c. Para anggota angkatan perang reguler yang menyatakan kesetiaannya pada suatu pemerintah atau kekuasaan yang tidak diakui oleh negara penahan.

d. Orang-orang yang menyertai angkatan perang tanpa dengan sebenranya menjadi anggota dari angkatan perang itu, seperti anggota sipil awak pesawat terbang militer, wartawan perang, anggota-anggota kesatuan kerja, dinasdinas yang bertanggung jawab atas kesejahteraan angkatan perang, asalkan mereka telah mendapatkan pengakuan dari angkatan perang yang disertainya

\footnotetext{
${ }^{6}$ Arlina Permanasari, dkk,. Pengantar Hukum Humaniter Internasional Committee of the Red Cross, Miamita Print, Jakarta, 1999, hlm. 164.

${ }^{7}$ Pasal 4A Konvensi Jenewa III Tahun 1949.
}

dan melengkap diri mereka dengan sebuah kartu pengenal.

e. Awak kapal niaga termasuk nakhoda, pandu laut, teruna serta awak pesawat terbang sipil dari pihak-pihak yang bersengketayang tidak mendapat eprlakuan yang lebih baik menurut ketentuan-ketentuan apapun dalam Hukum Internasional.

f. Penduduk wilayah yng belum diduduki, yang ketika musuh mendekat, atas kemauannya sendiri dan dengans serentak mengangkat senjata untuk melawan pasukan-pasukan yang datang menyerbu, tanpa memiliki waktu yang cukup untuk membentuk kesatuankesatuan bersenjata secara teratur, asal saja mereka membaw sebjata secara terbuka dan menghormati hukum dan kebiasaan perang.

Dari enam golongan tersebut diatas, poin a, b c termasuk dalam kategori kombatan, yang apabila tertangkap akan diperlakukan sebagai tawanan perang. Sedangkan poin $d$ dan e berada dalam kategori penduduk sipil, namun apabila mereka ditangkap oleh pihak musuh tetap behak mendapatkan status sebagai prisoner of war. ${ }^{8}$

Pasal 5 Konvensi Jenewa III sendiri menerangkan bahwa status tawanan perang mulai berlaku apabila seseorang telah memenuhi syarat yang ada dalam Pasal 4A dan $4 \mathrm{~B}$, dan sejak saat pemberlakuan itu mereka jatuh ke tangan musuh hingga saat pembebasan. Dalam Pasal 4B menjelaskan tentang orang yang akan diperlakukan sebagai tawanan perang ketika ditangan musuh : ${ }^{9}$

1) Orang yang tergolong atau pernah tergolong dalam angkatan pernag dari wilayah yang diduduki, apabila negara yang menduduki wilayah itu memandang perlu untuk menginternir mereka karena kesetiaan itu, walaupun negara itu semula telah membebaskan mereka selagi permusuhan berlangsung di luar wilayah yang diduduki negara itu, terutama jika orang-orang tersebut telah mencoba dengan tidak berhasil untuk bergabung kembali dengan angkatan

\footnotetext{
${ }^{8}$ Fritz Kanshoven, Constaint of The Waging of war, seconf edition, ICRC, Genewa, 2008, hal.41

${ }^{9}$ Pasal 4B Konvensi Jenewa III 1949
} 
perang mereka yang terlibat dalam pertempuran, atau jika mereka tidak memenuhi panggilan yang ditujukan kepada mereka berkenaan dengan penginterniran.

2) Orang-orang yang termasuk dalam salah satu golongan tersebut dalam Pasal ini, yang telah diterima oleh negara-negara netral atau negara-negara yang tidak turut berperang dalam wilayahnya, dan yang harus diinternir oleh negara-negara itu menurut hukum internasional, tanpa mempengaruhi tiap perlakuan yang lebih baik yang mungkin diberikan kepada mereka oleh negara-negara itu menurut hukum internasioanl, tanapa memperngaruhi tiap perlakuan yang lebih baik yang mungkin diberikan kepada mereka oleh negara-negara itu dan dengan perkecualian Pasal 8, 10, 15, 30 paragraf kelima Pasal 58, 67, 92, 126 dan apabila terdapat hubungan diplomatik antara pihak-pihak dalam sengketa dengan negara netral atau negara yang tidak turut berperang bersangkutan, Pasal-Pasal mengenai negara pelindungan.

J.G.Starke menjelaskan bahwa dalam suatu konflik bersenjata, pihak-pihak yang bertikai dibagi kedalam 2(dua) statusnya itu: ${ }^{10}$

1. Satu kelompok mempunyai status sebagai kombatan dan berhak ikut serta secara langsung dalam permusuhan, boleh membunuh dan dibunuh dan apabila tertangkap diperlakukan sebagai tawanan perang.

2. Sedang kelompok yang lain, memiliki status sebagai oang sipil (civilian) yang tidak boleh turut serta dalam permusuhan, harus dilindungi dan tidak boleh dijadikan sebagai sasaran serangan.

Kombatan sendiri terdiri atas 2 (dua) golongan yaitu: ${ }^{11}$

1) lawful combatant, akan mendapatkan perlindungan sebagai tawanan perang dan berstatus prisoner of war karena ia

\footnotetext{
${ }^{10}$ J.G.Starke, Pengantar Hukum Internasional, Terjemahan Bambang Iriana Djajatmadja, Sinar Grafika, Jakarta, 1989, hlm. 547

${ }^{11} \mathrm{lbid}$.
}

mengindahkan ketentuan Hukum Humaniter International;

2) unlawful combatant, mereka akan mendapatkan resiko yang lebih berat atau perlakuan khusus yang lebih keras apabila mereka tertangkap.

Karakteristik unlawful combantant ini ialah mereka yang ketika tertangkap tidak dianggap sebagai status tawanan perang atau prisoner of war (POW). ${ }^{12}$ Pengertian tersebut juga dijelaskan oleh penasihat hukum dari ICRC bahwa mereka ialah semua orang yang terlibat dalam suatu pertempuran atau peperangan tetapi mereka dianggap sebagai Prisoner of war ketika jatuh ketangan musuh, dan orang tersebut harus merupakan penduduk sipil. ${ }^{13}$ Yang menjadi contoh-contoh unlawful combatant antara lain :

a. Spionase, atau Mata-mata dalam Konvensi Den Haag IV diatur dalam Pasal 29 yang berbuny ${ }^{14}$ : "Seorang hanya dapat dianggap sebagai mata-mata apabila melakukan suatu perbuatan secara diam-diam atau berpura-pura untuk mencari dan memperoleh informasi didaerah oprasi dari negaranegara yang berperang dengan maksud untuk memberitahukannya kepada pihak musuh". Disetiap negara mengatur hukum tentang spionase dan menyatakan setiap kegitan spionase adalah sebuah bentuk kejahatan apabila negara tersebut menjadi sasaran kegiatan spionase itu sebabnya kegiatan Memata-matai/Spionase sangatlah beresiko. Konvensi Jenewa Protokol I memberikan definisi tentang status agent Mata-mata, sebagaimana tercantum dalam Pasal 46 ayat 1 yang berbunyi: ${ }^{15}$ Berdasarkan ketentuan pasal tersebut, apabila seorang angkatan bersenjata melakukan kegiatan Mata-mata dan jatuh kedalam kekuasaan lawan ia akan menerima kosekuensinya dengan tidak diberlakukan sebagai Tawanan Perang melainkan diperlakukan sebagai seorang

\footnotetext{
${ }^{12}$ Gary D. Solis, The Law Of Armed Conflict: International Humanitarian Law In War (Cambridge University Press,2010), hal .207

${ }^{13} \mathrm{lbid}$

${ }^{14}$ Pasal 29 Den Haag IV 1907

${ }^{15}$ Pasal 46 ayat 1Protokol Tambahan I 1977
} 
mata-mata, kecuali apabila mata-mata mengenakan seragam angkatan bersenjata atau dia sudah kembali pada satuannya walaupun dia melakukan kegiatan mata-mata dan jatuh di tangan musush dia tetap mendapatkan haknya sebagai tawanan perang seperti yang tertulis pada Pasal 46 ayat-ayat selanjutnya. ${ }^{16}$

b. Tentara bayaran (Merecenary), sering diartikan sebagai tentara yang bertempur dalam sebuah konflik bersenjata dengan motivasi utama berupa keuntungan materi dan kepentingan ideologi maupun paham politik. ${ }^{17}$ Pada umumnya tentara bayaran adalah mantan anggota tentara atau anggota tentara yang telah habis masa dinasnya. Umumnya mereka dipaksa dikeluarkan dari dinas militer karena sanksi yang diterimanya ataupun karena pengurangan personel dalam tubuh angkatan bersenjata. Di bawah Protokol Tambahan I tahun 1977 untuk Konvensi Jenewa tahun 1949, menjadi tentara bayaran bukanlah suatu kejahatan khusus. Mereka tidak dapat dijadikan sasaran serangan militer karena tidak termasuk dalam kelompok kombatan. ${ }^{18}$ Dalam Pasal 47 ayat (1) Protokol Tambahan I 1977 menyatakan: “ Seorang tentara bayaran tidak berhak atas status kombatan atau tawanan perang". ${ }^{19}$ Mereka dapat dituntut karena menjadi tentara bayaran hanya di bawah hukum nasional kekuasaan kehakiman jika memang terdapat ketentuan hukum yang menyatakan mercenaries sebagai distinct crime. ${ }^{20}$

c. Juvenile - Tentara Anak, Hukum Humaniter menempatkan ketentuan

\footnotetext{
${ }^{16} 1$ Febriyanto Rampengan, "Status Perlindungan Hukum Agen Mata-Mata Ditinjau Dari Hukum Humaniter Internasional", Lex Privatum Vol. V/No. 10,Des 2017, Hal .131

${ }^{17}$ Wirawan Sukarwo, Tentara Bayaran AS di Irak, Jakarta, Gagas Media, 2009.hlm. 35.

${ }^{18}$ Albert Camus, The Practical Guide to Humaniterian Law, guide-humaniterian-law.org.Diakses dari http://guidehumaniterian-

law.org/content/article/3/mercenaries/.Diakses pada tanggal 25 Juli 2020 pukul 23.26 WITA

${ }_{19}$ Pasal 47 ayat (1) Protokol Tambahan I 1977

${ }^{20}$ Albert Camus, The Practical Guide to Humaniterian Law, Loc.Cit.
}

tentang perlindungan anak dari perekrutan anak sebagai tentara diatur dalam Konvensi Jenewa IV tentang perlindungan penduduk sipil tahun 1949, ketentuan serupa juga diatur dalam Protokol Tambahan II Tahun 1977 yang melarang perekrutan anak sebagai tentara. ${ }^{21}$ Namun ada beberapa kasus terjadi dimana anak-anak atau yang masih dibawah umur bukannya dilindungi tetapi dijadikan sebagai pasukan yang ikut dalam pertempuran, yang mana mereka biasa disebut dengan tentara anak dimana seperti yang kita ketahui bahwa anak-anak harus dilindungi dalam perang menurut Hukum Humaniter Internasional. Penggunaan tentara anak ini selain melanggar Hukum Humaniter Internasional juga melanggar Hukum Perlindungan Anak-anak. Dalam Protokol Tambahan I, anak-anak memang tidak ditetapkan mempunyai hak untuk diperlakukan sebagai tawanan perang, melainkan mereka disebutkan harus memperoleh keuntungan Perlindungan Khusus yang ditetapkan dalam hukum Jenewa, terlepas apakah berstatus tawanan perang atau tidak. $^{22}$ Perlindungan Khusus tersebut terdapat dalam Pasal 77 Protokol Tambahan 1 1977 yaitu: ${ }^{23}$

1. Anak-anak harus dilindungi dari perbuatan-perbuatan yang tidak senonoh dan pihak yang bertikai harus menyediakan bantuan dan perawatan yang mereka butuhkan.

2. Pihak yang bersengketa harus mengambil segala tindakan dan menjauhkan anak-anak dari segala perekrutan anak tersebut menjadi tentara.

\footnotetext{
${ }^{21}$ I Gusti Widayanti, Dewa Gede Mangku, Ni Putu Yuliartini, "Penggunaan Tentara Anak Dalam Konflik Bersenjata Ditinjau Dari Perspektif Hukum Humaniter Internasiona", e-Journal Komunitas Yustisia Universitas Pendidikan Ganesha Program Studi IImu Hukum ,Volume 2 No,2019, hal.2

22 Fitra Amalia, Penggunaan Tentara Anak,Pelanggaran Terhadap Konvensi Jenewa,2019, Hal 2, https://www.kompasiana.com/fitrah92746/5dbc2cb4097f 361a8b1d6652/penggunaan-tentara-anak-pelanggaranterhadap-konvensi-jenewa?page $=2$ diakses pada 26 Juli 2020 pukul 14.59 WITA

${ }^{23}$ Pasal 77 Protokol Tambahan I 1977
} 
3. Tetapi dalam melatih anak yang berusia lima belas tahun tapi belum mencapai usia delapan belas tahun, maka mereka harus mengutamakan mereka yang tertua.

4. Perlindungan khusus yang diberikan kepada anak-anak ini diterapkan baik mereka dalam status tahanan maupun tidak; Apabila anak-anak ditangkap ditahan/ditawan, ataupun diasingkan karena hal-hal yang berkaitan dengan konflik bersenjata, mereka harus ditempatkan ditempat yang terpisah dengan orang dewasa, kecuali orang-orang dewasa tersebut adalah keluargannya.

5. Anak-anak tidak boleh dihukum mati.

Perlindungan hukum berdasarkan Protokol Tambahan II, yaitu pasal Pasal 4 ayat (3) huruf c telah memberikan pemaparan yang tegas mengenai keterlibatan anak dalam permusuhan atau konflik bersenjata yaitu dengan melarang anak-anak yang berusia di bawah lima belas tahun untuk direkrut dalam angkatan perang. Pasal 4 ayat (3) huruf d Protokol Tambahan II tahun 1977 memberikan pemahaman bahwa mereka yang berusia di bawah lima belas tahun atau belum mencapai umur lima belas tahun akan mendapatkan perlindungan istimewa jika mereka terlibat langsung dalam permusuhan apabila mereka tertangkap dan kemudian menjadi tawanan perang. Pasal 6 ayat (2) huruf $\mathrm{h}$ mengatur mengenai larangan pemberlakuan hukuman mati bagi mereka yang berusia di bawah delapan belas tahun pada saat pelanggaran itu dilakukan, larangan itu juga berlaku bagi ibu hamil dan ibu yang memiliki anak yang masih kecil. ${ }^{24}$

Seorang Tentara Anak dapat juga berstatus kombatan jika memenuhi unsur dalam Pasal $4 \mathrm{~A}$ ayat 2 , apabila saat menjadi kombatan para tentara anak ini menjadi tawanan perang maka hak-hak yang mereka dapatkan adalah hak-hak yang dimiiki oleh kombatan juga. ${ }^{25}$

Ketentuan tentang siapa yang berhak mendapatkan status dan perlakuan sebagai tawanan perang (prisoner of war) ini kemudian disempurnakan dalam Protokol I Tahun 1977 yang memberikan definisi baru dari apa yang

\footnotetext{
${ }^{24}$ I Gusti Widayanti1, Dewa Gede Mangku, Ni Putu Yuliartini, Op.Cit, Hal. 6-7

${ }^{25}$ Fitra Amalia, Op.Cit, Hal. 4
}

disebut sebagai Angkatan Bersenjata dan kombatan. Pasal 43 memberi batasan dari Angkatan Bersenjata sebagai berikut: ${ }^{26}$

1. Angkatan Bersenjata dari pihak yang bertikai terdiri dari Angkatan Bersenjata yang terorganisasi (organized armed porces), group dan unit yang berada di bawah komando yang bertanggung jawab atas kelakuan anak buahnya kepada pihak tersebut, sekalipun pihak itu diwakili oleh pemerintah atau penguasa (authority) yang tidak diakui oleh pihak lawan (adverse party). Angkatan Bersenjata tersebut harus tunduk kepada sistem disiplin kesatuan (internal diciplinary System) yang antara lain berisi pelaksanaan ketentuan hukum internasional yang berlaku dalam pertikaian bersenjata.

2. Anggota Angkatan Bersenjata dari pihak yang bertikai (kecuali personil medik dan pendeta seperti tersebut dalam Pasal 37 Konvensi Jenewa III) adalah kombatan, yaitu mereka yang berhak untuk turut serta secara langsung dalam permusuhan.

3. Apabila salah satu pihak yang bertikai memasukkan sebuah kesatuan (agency) para militer atau penegak hukum dalam Angkatan Bersenjata mereka, maka meraka wajib memberitahukan hal ini pada pihak-pihak lain yang bertikai.

Dalam Pasal 44 diatur tentang 'kombatan' dan 'tawanan perang' dengan ketentuanketentuan sebagai berikut: ${ }^{27}$

1) Setiap kombatan, seperti ditentukan dalam Pasal 43, yang jatuh dalam kekuasaan pihak lawan, akan menjadi tawanan perang (prisoner of war);

2) Sekalipun semua kombatan harus mentaati ketentuan-ketentuan hukum internasional yang berlaku dalam pertikaian bersenjata, namun pelanggaran ketetuan tersebut tidak akan menghilangkan haknya untuk menjadi kombatan apabila ia jatuh dalam kekuasaan pihak lawan, dan juga tidak menghilangkan haknya menjadi tawanan

\footnotetext{
${ }^{26}$ Haryo Mataram, Hukum Humaniter, Rajawali, Jakarta, 1984, hlm. 72-75.

${ }^{27}$ Ibid
} 
perang, kecuali apa yang ditentukan dalam ayat (3-4).

3) Untuk menambah perlindungan bagi penduduk sipil dari akibat permusuhan, kombatan diharuskan untuk membedakan diri dari penduduk sipil pada waktu mereka sedang menyerang atau di dalam suatu operasi militer yang mendahului serangan tersebut, tetapi mengingat dalam suatu pertikaian bersenjata terdapat situasi dimana mengingat sifat permusuhan tersebut, jika kombatan tidak dapat membedakan diri, ia akan tetap memperoleh statusnya sebagai kombatan asalkan dalam keadaan tersebut ia membawa senjata secara terbuka:

a) Selama setiap pertempuran (engagement) militer;

b) Selama ia dapat dilihat/keliatan oleh musuh pada waktu ia terlibat dalam suatu persiapan (deployment) militer mendahului serangan dimana ia turut serta. Perbuatan yang memenuhi ketentuan ini tidak boleh dianggap secara licik (perfidious) dalam Pasal 37 ayat (1c) berbunyi: "Pura-pura sebagai orang sipil, status bukan kombatan".

4) Seorang kombatan yang jatuh dalam kekuasaan pihak lawan sedang ia tidak memenuhi persyaratan yang ditentukan dalam kalimat kedua dari Pasal 3 (Orang yang tidak ambil bagian aktif dalam permusuhan dipelakukan secara manusiawi "Termasuk anggota militer yang sudah tidak ambil bagian aktif lagi karena sakit, cedera, atau tertawan.") akan kehilangan haknya sebagai tawanan perang, tetapi ia akan diberikan perlindungan yang sama dalam segala aspek seperti yang diberikan pada tawanan perang oleh Konvensi Jenewa III dan Protokol ini.

5) Setiap kombatan yang jatuh ke dalam kekuasaan pihak lawan, pada waktu (sedang) tidak terlibat dalam serangan atau dalam suatu operasi militer sebagai persiapan suatu serangan, tidak akan kehilangan haknya (forfeit) sebagai kombatan dan tawanan perang sebagai akibat kegiatan sebelumnya.
6) Pasal ini tidak mengurangi (without prejudice) hak setiap orang untuk menjadi tawanan perang sesuai dengan Pasal 4 Konvensi Jenewa III/yang membahas tentang kriteria-kriteria seseorang bisa berstatus sebagai tawanan perang).

7) Pasal ini tidak dimaksudkan untuk mengubah kebiasaan secara umum telah diterima negara-negara yang berhubungan dengan pemakaian seragam (uniform) oleh kombatan yang termasuk kesatuan yang reguler dan bersergam serta bersenjata (regular uniformed armed units) dari pihak yang bertikai.

8) Sebagai tambahan dari kategori orang tersebut dalam Pasal 13 Konvensi Jenewa III (Tawanan perang harus diperlakukan dengan perikemanusiaan, Tawanan perang juga harus selalu dilindungi, terutama terhadap tindakan-tindakan kekerasan atau ancaman-ancaman, dan terhadap penghinaan-penghinaan serta tontonan umum, Tindakan-tindakan pembalasan terhadap tawanan perang dilarang.), maka semua anggota Angkatan Bersenjata dari pihak bertikai seperti dirumuskan dalam Pasal 43 Protokol ini, berhak atas perlindungan yang diatur dalam Konvensi tersebut, apabila mereka terluka atau sakit, baik di darat maupun di laut.

Pasal 43 dan 44 menetapkan peserta perang adalah anggota angkatan bersenjata suatu pihak pada konflik bersenjata internasional, sedangkan dalam Pasal 45 pada intinya menyatakan bahwa apabila seorang yang ditangkap diragukan statusnya apakah dia kombatan atau penduduk sipil, maka ia akan tetap menikmati status sebagai tawanan perang sampai pengadilan yang bekompeten menetapankan status sebenarnya. ${ }^{28}$ Dalam Konvensi Jenewa IV disebutkan pula bahwa status tawanan perang tidak termasuk para nonkombatan yang tidak bersenjata yang ditangkap pada masa perang, mereka itu dilindungi. ${ }^{29}$

\footnotetext{
${ }^{28}$ Arlina Permatasari dkk, Pengantar Hukum Humaniter, op.cit, hlm 164

${ }^{29}$ Tahanan Perang, Loc.Cit
} 
B. Perlakuan Terhadap Tawanan Perang Menurut Hukum Humaniter Internasional

Hukum Kemanusiaan Internasional, Hukum Humaniter Internasional ( $\mathrm{HHI}$ ), yang seringkali disebut juga sebagai hukum konflik bersenjata (bahasa Inggris: International Humanitarian Law), adalah batang tubuh hukum yang mencakup Konvensi Jenewa dan Konvensi Den Haag berserta perjanjian-perjanjian, yurisprudensi dan hukum kebiasaan internasional yang mengikutinya. ${ }^{30}$ Hukum Humaniter Internasional menetapkan perilaku dan tanggung jawab negara-negara yang berperang, negara-negara netral dan individuindividu yang terlibat peperangan, yaitu terhadap satu sama lain dan terhadap orangorang yang dilindungi, bisanya berarti orang sipil.

Hukum Humaniter Internasional adalah wajib bagi negara yang terikat oleh perjanjianperjanjian yang relevan dalam hukum tersebut. Ada juga sejumlah aturan perang tak tertulis yang merupakan kebiasaan, yang banyak diantaranya dieksplorasi dalam Pengadilan Perang Nurenberg. Dalam pengertian yang diperluas, aturan-aturan tak tertulis ini juga menetapkan sejumlah hak permisif serta sejumlah larangan perilaku bagi negara-negara berperang bila mereka berurusan dengan pasukan yang tidak reguler atau dengan pihak non-penandatangan. Pelanggaran hukum kemanusiaan internasional disebut kejahatan perang. ${ }^{31}$

Di dalam suatu konflik bersenjata atau perang maka selalu ada akibat yang timbul yaitu banyak menimbulkan korban, baik itu kombatan maupun penduduk sipil. Mau tak mau maka akan terjadi penahanan terhadap kombatan yang tertangkap yang masih dalam keadaan hidup, apakah masih dalam keadaan baik-baik saja ataupun dalam keadaan terluka. Tapi tidak bisa disangkal bahwa tawanan perang ini akan mengalami hal-hal yang mengerikan selama mereka dalam tahanan sebagai tawanan perang. Akibat yang mengerikan yang terjadi terhadap kombatan maupun penduduk sipil seperti yang diceritakan oleh Henry Dunant dalam perkembangannya mendapat pengaturan dalam beberapa

\footnotetext{
${ }^{30}$ ICCR What is international humanitarian law?, diakses pada tanggal 17 Mei 2020

${ }^{31}$ Tahanan Perang, Loc-Cit
}

konvensi seperti Konvensi Den Haag 1907, Konvensi Jenewa 1949 serta Protokol Tambahan I dan II Tahun 1977.

Konvensi-konvensi Jenewa 1949 serta Protokol Tambahan tentang Perlindungan Korban Perang (Geneva Convention of 1949 for The Protection of victims of war) terdiri atas 4 (empat) konvensi, yaitu: ${ }^{32}$

1) Konvensi Jenewa untuk Perbaikan Keadaan yang luka dan Sakit dalam Angkatan Bersenjata di Medan Pertempuran Darat (Geneva Convention for the Amelioration of the Condition of the Wounded and Sick in Armed Forces in the Field, of August 12, 1949).

2) Konvensi Jenewa untuk Perbaikan Keadaan Anggota Angkatan Bersenjata di Laut yang Luka, Sakit dan Korban Karam (Geneva Convention for the Amelioration of the Condition of wounded, Sick, and Shipwrecked Members of Armed Forces at Sea, of August 12, 1949).

3) Konvensi Jenewa mengenai Perlakuan Tawanan Perang (Geneva Convention relative to the Treatment of Prisonesr of War, of August 12, 1949).

4) Konvensi Jenewa mngenai Perlindungan Orang Sipil di Waktu Perang (Geneva Convention relative to the Protection of Civilian Persons in time of War, of August 12, 1949).

Berkaitan dengan judul skripsi ini, maka yang akan dibahas adalah Konvensi Jenewa yang ke-3 dan Protokol Tambahan I Tahun 1977. Dalam Konvensi Jenewa III ditentukan bahwa negara penahan wajib bertanggung jawab atas perlakuan yang diberikan kepada tawanan-tawanannya. Tawanan yang dimaksud adalah tawanan negara musuh, yaitu orangperorangan yang merupakan kombatan dari negara musuh. Dalam hal ini, kombatan negara musuh yang menjadi tawanan mempunyai suatu perlindungan hukum dan tetap mendapatkan hak-haknya.

Pengaturan mengenai perlindungan terhadap tawanan perang dapat ditemui di

\footnotetext{
${ }^{32}$ Lona Puspita, Perlindungan Hukum Terhadap Tawanan Perang Berdasarkan Konvensi Jenewa III Tahun 1949 dan Declaration of Human Rights, diakses dari https://osf.io> download pada tanggal 17 Juli 2020.
} 
dalam pasal-pasal pada Konvensi Jenewa III, diantaranya: ${ }^{33}$

1. Pasal13 ayat (1):

Pasal ini mengatur mngenai kewajiban negara penahan untuk memperlakukan tawanan perang berdasarkan prinsipprinsip hukum humaniter internasional yang salah satunya adalah prinsip kemanusiaan. Dalam hal ini Tawanan perang terutama tidak boleh dijadikan obyek pengudungan jasmani, percobaanpercobaan kedokteran atau ilmiah dalam bentuk apapun juga yang tidak dibenarkan oleh pengobatan kedokteran, kedokteran gigi atau kesehatan dari tawanan bersangkutan dan dilakukan demi kepentingannya.

2. Pasal 13 ayat (2):

Pasal ini berisi larangan dilakukannya penganiayaan, kekerasan fisik maupun non fisik serta penghinaan. Dalam pasal ini sudah sangat jelas bahwa negara penahan tidak boleh menggunaan kekerasan pada seorang tawanan perang, jika terjadi hal-hal tersebut sampai membahayakan nyawa dari tawanan perang tersebut akan dianggap pelanggaran berat dalam konvensi ini.

3. Pasal 25 sampai dengan Pasal 28 :

Pasal-pasal ini memberikan pengaturan mengenai kewajiban negara penahan untuk memberi jaminan atas sandang, pangan dan papan bagi para tawanan perang. Dalam hal ini negara penahan wajib memberikan pakaian, makanan, serta tempat tinggal kepada tawanan perang karena itu adalah kebutuhan yang mendasar pada manusia. Tawanan perang harus diberi tempat tinggal sesuai syarat-syarat yang diberikan kepada tentara Negara Penahan yang ditempatkan di daerah yang sama. Rangsum makanan harian pokok harus cukup berkwalitas, kwantitas dan macam-macamnya untuk memelihara kesehatan yang baik dari tawanan perang dan untuk mencegah berkurangnya berat badan atau timbulnya penyakit kekurangan makanan, dan Kantin-kantin harus diadakan di semua tempat tawanan di mana tawanan perang dapat memperoleh bahan makanan, sabun dan tembakau serta barang kebutuhan sehari-hari. ${ }^{34}$

4. Pasal 29 sampai dengan Pasal 32:

Pasal-pasal ini memberikan pengaturan mengenai kewajiban negara untuk memelihara dan merawat kesehatan tawanan perang. Dalam hal ini Negara Penahan wajib mengambil segala tindakan kesehatan yang diperlukan untuk menjamin bahwa tawanan perang akan bertahan dan tekena wabah-wabah menular selama berada dibawah perintah musuh, Setiap kamp tawanan harus mempunyai rumah sakit yang cukup memenuhi syarat di mana tawanan perang dapat memperoleh pengamatan kesehatan yang mereka perlukan, begitupun juga makanan yang tepat, Pemeriksaan kesehatan tawanan perang harus diadakan sekurangkurangnya sekali sebulan dan Tawanan perang yang menjadi dokter, ahli bedah, dokter gigi, perawat atau tenaga pembantu kesehatan, dapat diwajibkan oleh Negara Penahan untuk menjalankan fungsi mereka dibidang kesehatan mereka bagi kepentingan tawanan perang yang menaati Negara yang sama, walaupun mereka itu tidak tergolong dalam dinas kesehatan angkatan perangnya. $^{35}$

5. Pasal 34 sampai dengan Pasal 42 :

Pasal-pasal ini memberikan pengaturan mengani kewajiban negara penahan untuk menjamin kebebasan tawanan perang untuk melakukan kegiatan keagamaan, intelektual serta jasmani. Dalam hal ini Tawanan perang harus memperoleh kebebasan penuh dalam mejalankan kewajiban keagamaan mereka, Para Rokhaniawan yang jatuh dalam tangan Negara musuh harus diperkenankan untuk menyelenggarakan dan menjalankan secara bebas bantuanbantuan keagamaan di antara tawanan perang dari agama yang sama sesuai dengan hati nurani keagamaan mereka, Tawanan perang yang menjadi petugas-

\footnotetext{
${ }^{34}$ Rangkuman pasal 25-25 Konvensi Jenewa III 1949

${ }^{35}$ Rangkuman pasal 29-32 Konvensi Jenewa III 1949
} 
petugas keagamaan harus bebas untuk memberikan bantuan kerohanian kepada angauta-anggota mereka apapun juga golongannya, Jika tawanan perang tidak mendapat bantuan dari seorang rohaniwan atau petugas keagamaan mereka maka harus diangkat mengisi jabatan itu dan harus ada persetujuan dari negara penahan, Negara Penahan harus memberikan dorongan pada kegiatan-kegiatan intelektual, pendidikan, hiburan, olah raga serta permainan-permainan bersama di antara tawanan. $^{36}$

6. Pasal 58 sampai dengan Pasal 68:

Pasal-pasal ini memberikan pengaturan mengenai kewajiban negara penahan untuk membayarkan sejumlah uang muka dan upah bagi tawanan perang yang dipekerjakan. Dalam pasal-pasal ini intinya mengatur tentang sumbersumber keuangan terhadap Tawanan Perang.

7. Pasal 69 sampai dengan Pasal 77:

Pasal-pasal ini memberi pengaturan mengenai kewajiban negara untuk memenuhi hak tawaan perang dalam melakukan hubungan dengan dunia luar. Dalam hal ini tawanan perang behak menulis surat atau kartu untuk dikirim kepada keluarganya dan juga berhak menerima surat, dimana negara penahan yang menyediakan fasilitas penyaluran yang diperuntukan tawanan perang atau dikirim untuk mereka, dapat juga menerima dengan pos atau dengan cara lain baik bingkisan-bingkisan perorangan atau kiriman-kiriman kolektip yang terutama berisi bahan makanan, pakaian, obat-obatan serta barang-barang. Semua sumbangan untuk tawanan perang harus dibebaskan dari pajak pemasukan, bea cukai dan biaya-biaya lainnya. Bila operasi-operasi militer mencegah Negara-negara yang bersangkutan untuk memenuhi kewajibannya menjamin pengangkutan kiriman-kiriman tersebut maka Negara-negara Pelindung yang bersangkutan dapat bertindak untuk menjamin pengangkutan kiriman

\footnotetext{
${ }^{36}$ Rangkuman pasal 32-42 Konvensi Jenewa III 1949
}

tersebut dengan alat-alat yang memadai. Dan penyensoran surat-menyurat yang dialamatkan kepada tawanan perang atau yang dikirim oleh mereka harus dilakukan secepat mungkin. ${ }^{37}$

8. Pasal 78:

Pasal ini memberi pengaturan mengenai kewajiban negara untuk memberikan hak kepada tawanan perang yang ingin melakukan pengaduan terhadap keadaan dan perlakuan yang ditujukan kepadanya kepada para penguasa militer atau kepada para wakil negara pelindung. Dalam hal ini Permohonan dan pengaduan tidak boleh dibatasi, juga tidak boleh dianggap sebagai bagian jatah surat-menyurat sebagaimana ditentukan dalam Pasal 71(Tawanan perang harus diperkenankan mengirim serta menerima surat-surat dan $\mathrm{kartu}^{38}$ ). Permohonan dan pengaduan ini harus diteruskan dengan segera. Permohonan dan pengaduan ini tidak boleh mengakibatkan hukuman apapun, sekalipun kemudian ternyata bahwa permohonan atau pengaduan itu tidak beralasan.

9. Pasal 99 sampai dengan Pasal 108:

Pasal-pasal ini memberikan pengaturan mengenai kewajiban negara penahan untuk menjamin terselenggaranya pengadilan yang bebas tanpa memihak bagi para tawanan perang. Dalam hal ini menyebutkan bahwa Tawanan perang tidak boleh diadili atau dijatuhi hukuman untuk perbuatan yang tidak dilarang oleh Undang-undang Negara Penahan atau oleh hukum internasional yang berlaku, Untuk itu Negara-negara Pelindung harus diberitahu selekas mungkin tentang jenis pelanggaran yang menurut undangundang Negara Penahan dapat dihukum dengan hukuman mati. Apabila hukuman mati dijatuhkan atas diri seorang tawanan perang, keputusan itu tidak boleh dijalankan sebelum lewat waktu sekurang-kurangnya enam bulan mulai dari saat Negara Pelindung menerima pemberitahuan, dan Seorang tawanan perang hanya dapat dihukum dengan sah

\footnotetext{
${ }^{37}$ Rangkuman pasal 69-77 Konvensi Jenewa III 1949

${ }^{38}$ Pasal 71 Konvensi Jenewa III 1949
} 
apabila hukuman dijatuhkan oleh pengadilan. Pemeriksaan pendahuluan terhadap seorang tawanan perang harus dilakukan secepat keadaan mengizinkan, sehingga ia dapat diadili selekas mungkin. Jika Negara Penahan telah memutuskan mengadakan pemeriksaanpemeriksaan di pengadilan terhadap seorang tawanan perang, Negara Penahan harus memberitahukannya kepada Negara Pelindung selekas mungkin dan sekurang-kurangnya tiga minggu sebelum peradilan dimulai, dan Tawanan perang berhak akan bantuan salah seorang kawan tawanannya untuk menjadi seorang pembela atau pengacara dan berhak memanggil saksi, dalam hal ini setiap tawanan perang berhak mengajukan banding atau petisi untuk membatalkan atau merobah hukuman yang dijatuhkan terhadapnya. Tiap keputusan dan hukuman yang dijatuhkan atas diri seorang tawanan perang harus segera dilaporkan kepada Negara Pelindung dalam bentuk pemberitahuan singkat. Ketika hukuman yang akan dijalani oleh tawanan perang harus dijalani dalam bangunan yang sama dan menurut keadaan dan syaratsyarat yang sama seperti apa yang berlaku bagi anggota-anggota angkatan perang Negara Penahan. ${ }^{39}$

\section{PENUTUP}

\section{A. Kesimpulan}

1. Hukum Humaniter Internasional menentukan bahwa seseorang yang berstatus sebagai combatant (dalam hal ini lawful combatant) otomatis berhak diperlakukan sebagai tawanan perang (prisoner of war) apabila mereka tidak mampu lagi melanjutkan pertempuran dan tertangkap pihak lawan. Tetapi ada juga sekelompok penduduk sipil tertentu, walaupun mereka bukan kombatan, apabila jatuh ke tangan musuh berhak pula mendapatkan status prisoner of war sebagaimana yang diatur dalam Pasal $4 \mathrm{~A}$ dan 4B Konvensi Jenewa III Tahun 1949. Ketentuan tentang siapa yang berhak mendapatkan status dan perlakuan sebagai tawanan perang (prisoner of war) telah disempurnakan dalam Protokol I Tahun 1977, diatur dalam pasal 43,44, 45. Kemudian dalam Konvensi Jenewa IV disebutkan pula bahwa status tawanan perang tidak termasuk para nonkombatan yang tidak bersenjata saat ditangkap pada masa perang, mereka itu dilindungi.

2. Tawanan perang itu harus diperlakukan dengan baik karena hak-hak mereka diatur didalam Konvensi Jenewa III Tahun 1949 yaitu hak mendapatkan perlakuan manusiawi, hak kehormatan martabat dan harga diri, hak perawatan medis, hak memperoleh perlakuan yang adil, hak melaksanakan ritual keagamaan, hak aktivitas mental dan fisik, hak mendapatkan kebutuhan primer seperti sandang, pangan dan papan dan hak berkomunikasi dengan dunia luar.

\section{B. Saran}

1. Tawanan perang adalah manusia biasa yang kemudian terlibat dalam perang karena keadaan dimana negaranya terlibat dalam suatu peperangan, oleh karena itu hal-hal yang diatur dalam Konvensi Jenewa III Tahun 1949 dan Protokol Tambahan I tahun 1977 harus ditaati dan dilaksanakan dengan sebaikbaiknya oleh negara-negara yang terlibat dalam peperangan. Mereka harus mendapatkan perlakuan yang sepantasnya sebagai seorang manusia yang mempunyai Hak Asasi Manusia.

2. Sebisa mungkin perang itu dihindari oleh suatu negara yang sedang mengalami konflik internal didalam negaranya sendiri maupun konflik antar satu negara dengan negara lainnya, agar penduduk sipil tidak menjadi korbannya yang seharusnya bisa menjadi penerus bangsa tapi harus menjadi korban dalam konflik bersenjata.

\section{DAFTAR PUSTAKA}

Mataram, Haryo. 1984. Hukum Humaniter. Jakarta: Rajawali

\footnotetext{
${ }^{39}$ Rangkuman pasal 99-108 Konvensi Jenewa III 1949
} 
Permatasari, Arlina dkk. 1999. Pengantar Hukum Humaniter. ICRC. Jakarta: Miamita Print

Ambarwati,Denny.R, Rina.R.2012. Hukum Humaniter Internsional Dalam Hubungan Intenasional. Jakarta: Pt Raja Grafindo Persedo

Soekanto, Soerjono. 2001. Penelitian Hukum Normatif, Suatu Tinjauan Singkat. Persada: RajaGrafindo

Starke J.G. 1989. Pengantar Hukum Internasional.Terjemahan Bambang Iriana Djajatmadja. Jakarta: Sinar Grafika

Haryomataram, KPHG. 2012. Pengantar Hukum Humaniter.Jakarta: Raja Grafindo Persada

Yulia, Lia. 2015. Konteks Dan Perspektif Politik Terkait Hukum HumaniterInternasional Kontemporer. Jakarta : RajaGrafindo Persada

Putri Ria Wierma. 2012. Hukum Humaniter Internasional, Bandar Lampung: Universitas Lampung

Effendi, A. Mashyur dan Taufanis, Evandri. 2010. HAM Dalam Dinamika/Dimensi Hukum,Politik Ekonomi, dan Sosial, Bogor: Ghalia Indonesia

Gasser Hans Peter dalam Hanung Hisbullah Hamda, Konsep Perlindungan Tawanan Perang Menurut Hukum Humaniter Internasional dan Hukum Islam, Jurnal Hukum No.30 Vol 12 September 2005

Green, Leslie. 2008. The Contemporary Law of Armed Conflict, Juris Published, Manchester University Press.

Istanto, Sugeng. 1994. Hukum Internasional, Yogyakarta: Universita Atmajaya Yogyakarta

Kanshoven, Fritz. 2008. Constaint of The Waging of war, seconf edition, ICRC: Genewa

Tavel, Harroff, Marion. 1993 .Kegiatan Komite Internasional Palang Merah (ICRC) Pada Waktu Kekerasan Dalam Negeri, terj. ICRC Delegation Jakarta, Jakata: ICRC Publication,

R. Sianturi. 2010. Hukum Pidana Militer di Indonesia, Jakarta: Badan Pembinaan

Hukum Tentara Nasional Indonesia

Latuputty Herryanto Marcelino. 2016. " Status Hukum Pihak-Pihak Yang Bertikai Dalam Konflik Berse njata Di Suriah Berdasar
Hukum Humaniter Internasional", Hubungan Internasional.

Rusman,Rina. 2004. Beberapa Perkembangan Hukum Humaniter Internasional.

Jakarta: Makalah disampaikan dalam Kursus Dasar HHI dan Ham untuk Dosen Perguruan Tinggi Negeri dan Swasta yang diselenggarakan di Banjarmasin atas kerja sama antara Fakultas Syari'ah IAIN Antasari dan ICRC Delegasi.

Mataram, Haryo, GPH. 1994. Sekelumit Tentang Hukum Humaniter. Surakarta: Sebelas Maret University Press

Lachs, Manfred, and Cristopher Swinarski (Ed). 1984. Responsibility For The Development of Humanitarian Law, Studies and Essay on International Humanitarian Law and Red Cross Principles, Laiden: Martinus Nijhoff Publisher.

Wagiman, Wahyu. 2014. Hukum Humaniter dan Hak Asasi Manusia. Makalah yang disampaikan pada Kursus HAM untuk Pengacara XI.

Rudy, T. May. 2001, Hukum Internasional 2, Bandung: Refika Aditama

Shaw, Malcolm. 1997. International Law, Fourth Edition, Cambridge : Grotius Publication

Alston Philip dan Franz Magnis-suseno. 2008. "Hukum Hak Asasi Manusia", Yogyakarta: Pusat Studi Hak Asasi Manusia Universitas Islam Indonesia.

Triana, Nita. Jul-Des 2009.Perlindungan Perempuan dan Anak Ketika Perang Dalam Hukum Humaniter Internasional. Jurnal Studi Gender \& Anak, Pusat Studi Gender STAIN Purwokerto,YINYANG Vol. 4. No 2 pp. 320-334. ISSN: 1907-2791.

Kusumo, Ayub dan Kukuh Tejomutri, 2015. "Alternatif atas Pemberlakuan Hukum Humaniter Internasional dalam Konflik Bersenjata Melawan Islamic State of Iraq and Syria", Yustisia. Vol. 4 No. 3

DANIAL, 2015, “Penghormatan prinsip-prinsip kemanusiaan terhadap tawanan perang dalam konflik bersenjata menurut onvensi Jenewa III Tahun 1949", Jurnal Idea Hukum Vol. No. 2, Magister Hukum Fakultas Hukum Universitas Jenderal Soedirman

ICRC, Commentary on the Additional Protocol of June 1977, Claude Pilloud et all, with the collaboration of jean Picted, Yves Sandoz, 
ed, Martinus Nijoff Publishers, Geneva 1987,

Pietro, Verri.1992. Dictionary of the International Law of Armed Conflict, ICRC, Geneve

Solis Gary D, 2010, The Law Of Armed Conflict: International Humanitarian Law In War ,Ingris: Cambridge University Press.

Rampengan, Febriyanto, Des 2017, "Status Perlindungan Hukum Agen Mata-Mata Ditinjau Dari Hukum Humaniter Internasional", Lex Privatum Vol. V/No. 10 International Commite Of The Red Cross, 2008. "Hukum Humaniter Internasiona;Komite Internasional Palang Merah "ICRC Delegasi Indonesia,Jakarta:ICRC Publications.

Sukarwo Wirawan , 2009 Tentara Bayaran AS di Irak, Jakarta:Gagas Media.

I Gusti Widayanti, Dewa Gede Mangku, Ni Putu Yuliartini, 2019, "Penggunaan Tentara Anak Dalam Konflik Bersenjata Ditinjau Dari Perspektif Hukum Humaniter Internasiona", e-Journal Komunitas Yustisia Universitas Pendidikan Ganesha Program Studi Ilmu Hukum, Volume 2 No.

Mirsa Prajodi, Handojo.L, Ayub T. S. K, Konflik Bersenjata Di Wilayah Ukraina Tahun 2014 Menurut Hukum Humaniter Internasional , Belli ac Pacis. Vol. 1. No.1 Juni

Gillard, Emanuela-Chiara, Business Goes to War: Private Military/Security Companies and International Humanitarian Law, International Review of the Red Cross. Vol. 88, No. 836, September 2006.

Michael N. Schmitt, Humanitarian Law and Direct Participation in Hostilities by Private Contractors or Civilian Employees, Chicago Journal of International Law. Vol. 5, Januari 2005 